УДК 631.11

\title{
ТРУДОРЕСУРСНЕ ЗАБЕЗПЕЧЕННЯ ФУНКЦІОНУВАННЯ АГРАРНОГО СЕКТОРУ КРІЗЬ ПРИЗМУ СТАЛОГО РОЗВИТКУ СІЛЬСЬКИХ ТЕРИТОРІЙ
}

\section{LABOR SUPPORT FOR THE FUNCTIONING OF THE AGRICULTURAL SECTOR THROUGH THE PRISM OF SUSTAINABLE DEVELOPMENT OF RURAL AREAS}

\author{
Поленкова Марина Володимирівна \\ кандидат економічних наук, доцент, \\ Національний університет «Чернігівська політехніка» \\ ORCID: https://orcid.org/0000-0003-1571-6792 \\ Polenkova Maryna \\ Chernihiv Polytechnic National University
}

У статті обгрунтовано стратегічну роль аграрного сектору у процесі соціально-економічного розвитку країни. Охарактеризовано засади сталого розвитку сільського господарства. Запропоновано послідовність оцінювання структурних змін. Розраховано індекс, швидкість та інтенсивність структурних змін трудоресурсного забезпечення у процесі функціонування сільськогосподарських підприємств. Визначено період, протягом якого здійснювався найбільший структуро-утворювальний вплив трудоресурсного забезпечення на фрункціонування аграрних підприємств. Обгрунтовано, що сильним негативним впливом на соціально-економічний розвиток України відзначився період поширення та загострення COVID-19, проте підприємства аграрного сектору за усіма видами діяльності продовжують функціонувати без особливих обмежень. Окреслено напрями Спільної аграрної політики сталого розвитку сільського господарства ЄС.

Ключові слова: сільськогосподарські підприємства, трудоресурсне забезпечення, аграрний сектор, структурні зміни.

В статье обосновано стратегическую роль аграрного сектора в процессе социально-экономического развития страны. Охарактеризованы принципы устойчивого развития сельского хозяйства. Предложена последовательность оценки структурных изменений. Рассчитан индекс, скорость и интенсивность структурных изменений трудоресурсного обеспечения в процессе фрункционирования сельскохозяйственных предприятий. Определен период, в течение которого осуществлялося наибольшее структурное влияние трудоресурсного обеспечения на функционирование аграрных предприятий. Обосновано, что сильным негативным влиянием на социально-экономическое развитие Украины отличился период распространения и обострения COVID-19, однако предприятия аграрного сектора по всем видам деятельности продолжают срункционировать без особых ограничений. Определены направления Общей сельскохозяйственной политики устойчивого развития сельского хозяйства ЕС.

Ключевые слова: сельскохозяйственные предприятия, трудоресурсное обеспечение, аграрный сектор, структурные изменения.

The article substantiates the strategic role of the agricultural sector in the process of socio-economic development of the country. The principles of sustainable development of agriculture are described. The sequence of estimation of structural changes is offered. The index, speed and intensity of structural changes of labor supply in the process of functioning of agricultural enterprises are calculated. The period during which the greatest structural and formative influence of labor supply on the functioning of agricultural enterprises was carried out is determined. The results of the calculations show the greatest structural and formative impact of labor resources on the functioning of agricultural enterprises in 2014, where the intensity of structural changes became the most important. It is important to note that such an impact was observed only in the field of crop production, while the labor supply of livestock since 2014 has been relatively stable, but low. It is substantiated that the period of spread and aggravation of COVID-19 was marked by a strong negative impact on the socio-economic development of Ukraine, but the enterprises of the agricultural sector in all types of activities continue to operate without special restrictions. It is determined that the Common Agricultural Policy (CAP) of the European Union is a model example of support for agriculture in the con- 
text of sustainable development of the country, in particular rural areas. The directions of the Common Agrarian Policy of Sustainable Development of EU Agriculture are outlined. Today in Ukraine there is a situation when the state can not fully provide the population with guarantees for all social aspects of its quality of life. Therefore, the most active part of society - entrepreneurs must begin to find their own methods of solving socio-economic problems. Nowadays, agribusiness integrates and combines the functional set of all areas of the agricultural sector, which, in turn, provides the basic needs of society in food. In addition to the production of quality products and services, agricultural enterprises are obliged to assume additional obligations to society for the performance of various socially important tasks in the context of sustainable development of rural areas.

Keywords: agricultural enterprises, labor supply, agricultural sector, structural changes.

Постановка проблеми. Сталий розвиток сільського господарства базується на принципі необхідності задоволення потреб сьогодення без шкоди для здатності майбутніх поколінь забезпечувати свою життєдіяльність і задовольняти власні потреби. Так, довгострокове управління природними та людськими ресурсами має однакове значення для короткострокової економічної вигоди. Управління людськими ресурсами включає врахування соціальних потреб і обов'язків, таких як умови праці та життя працівників, потреби сільських громад, а також здоров'я та безпека споживачів як сьогодні, так і в майбутньому. Підприємства аграрного сектору сьогодні все частіше відчувають тиск на вирішення соціальних проблем, шкоду навколишньому середовищу в їх ланцюгах постачання, а також потребують пошуку шляхів вирішення критично важливих соціально-економічних та екологічних завдань, встановлених у відповідності до цілей сталого розвитку.

Аналіз останніх досліджень і публікацій. Теоретичні засади трудових відносин, праці та зайнятості висвітлені у працях А. Азріліяна, М. Агафонова, В. Адамчука, В. Баутіна, І. Кириленка, Р. Колосова, Ю. Коніна, В. Куценка, А. Маршалла, Г. Мелікьяна, Л. Мельника, Л. Мельник, І. Опалаєва, С. Сергєєва, В. Удовиченка, В. Яковлєва. Питанням формування та використання трудоресурсного потенціалу в аграрному секторі присвятили свої наукові роботи Е. Атаманюк, О. Бородіна, С. Кафрлевська, О. Кузьмак, В. Міга, Т. Мисник, Т. Сус, $€$. Ходаківський, В. Ярова та ін. Попри значний науковий доробок на сьогодні залишається ще багато проблем, пов'язаних із оцінкою ефективності використання економічно активного населення у сільському господарстві; відтворенням трудового потенціалу сільських територій та альтернативної зайнятості; розробкою ефективних механізмів розвитку підприємств аграрного сектору в умовах сталого розвитку сільських територій.

Завданням даної статті є обгрунтування трудоресурсного забезпечення фрункціону- вання аграрного сектору крізь призму сталого розвитку сільських територій.

Виклад основного матеріалу дослідження. Аграрний сектор відіграє стратегічну роль у процесі соціально-економічного розвитку країни. Збільшення сільськогосподарського виробництва та зростання доходу сільського населення разом із індустріалізацією та урбанізацією призводять до збільшення попиту на промислове виробництво. При цьому можна виокремити декілька аспектів впливу сільського господарства на соціальноекономічний розвиток, зокрема: забезпечуючи продуктами харчування та сировиною інші сектори економіки; формуючи попит на товари, що виготовлені в інших секторах сільським населенням за рахунок посилення купівельної спроможності від сільськогосподарської діяльності; забезпечуючи фрормування надлишкових інвестицій у формі заощаджень та податків, які інвестуються в інші сектори; акумулюючи (заробляючи) цінні іноземні валюти за рахунок експорту сільськогосподарської продукції; забезпечуючи роботою значної кількості некваліфрікованої робочої сили [5].

Диверсифрікація засобів існування та зайнятість у несільських господарствах $€$ важливими важелями економічного зростання в сільській місцевості. Наприклад, у країнах, що розвиваються, успіх Зеленої революції призвів до ідеї "унімодальної" аграрної структури. Вважалося, що сільськогосподарське зростання за допомогою стратегій підвищення продуктивності може створити мультиплікатори зростання в економіці, що призведе до загального зростання доходів та створення зайнятості. Хоча зростання сільського господарства сприяло зростанню та структурним перетворенням у багатьох країнах, демографрічний тиск, перевага невеликих фрермерських господарств, зменшення частки доходів домогосподарств від сільського господарства та комерціалізації змінили роль сільського господарства у майбутньому економічному зростанні [1; 4]. 
Економічні зміни змінили роль культури, установ, статі та доступу до людського капіталу в сільській місцевості. У той же час якісна освіта та інсрраструктура охорони здоров'я, окрім питання доступу до землі та інших природних ресурсів стають все більш важливими. Отже, шлях стратегії розвитку, якого дотримується країна, є головним у збалансуванні “продовольчого рівняння".

У процесі цього дослідження важливим $€$ оцінювання структурних змін у трудоресурсному потенціалі аграрного сектору, яке вважаємо доцільним провести за відповідною методикою (рис. 1). При цьому основою для розрахунків (масою структурних змін) слугуватимуть показники частки зайнятих працівників на сільськогосподарських підприємствах від загальної кількості зайнятих за основними напрямами сільськогосподарської діяльності (рослинництва і тваринництва) протягом 2010-2019 рр.

Базовим періодом (МОТР) визначено 2010 р. - початок відносного економічного посткризового пожвавлення (табл. 1).

Результати розрахунків засвідчують найбільший структуро-утворювальний вплив трудоресурсного забезпечення на фрункціонування аграрних підприємств у 2014 р., де показник інтенсивності структурних змін набув найбільшого значення - “1,257". При цьому важливо відзначити, що такий вплив простежувався тільки у сорері рослинництва - "1,344", натомість трудоресурсне забезпечення тваринництва, починаючи з 2014 р. було відносно стабільним, проте низьким (рис. 2).

Такі тенденції пов'язані із низкою процесів, що відбулися у сільському господарстві України у 2014 р., серед яких [2; 3]:

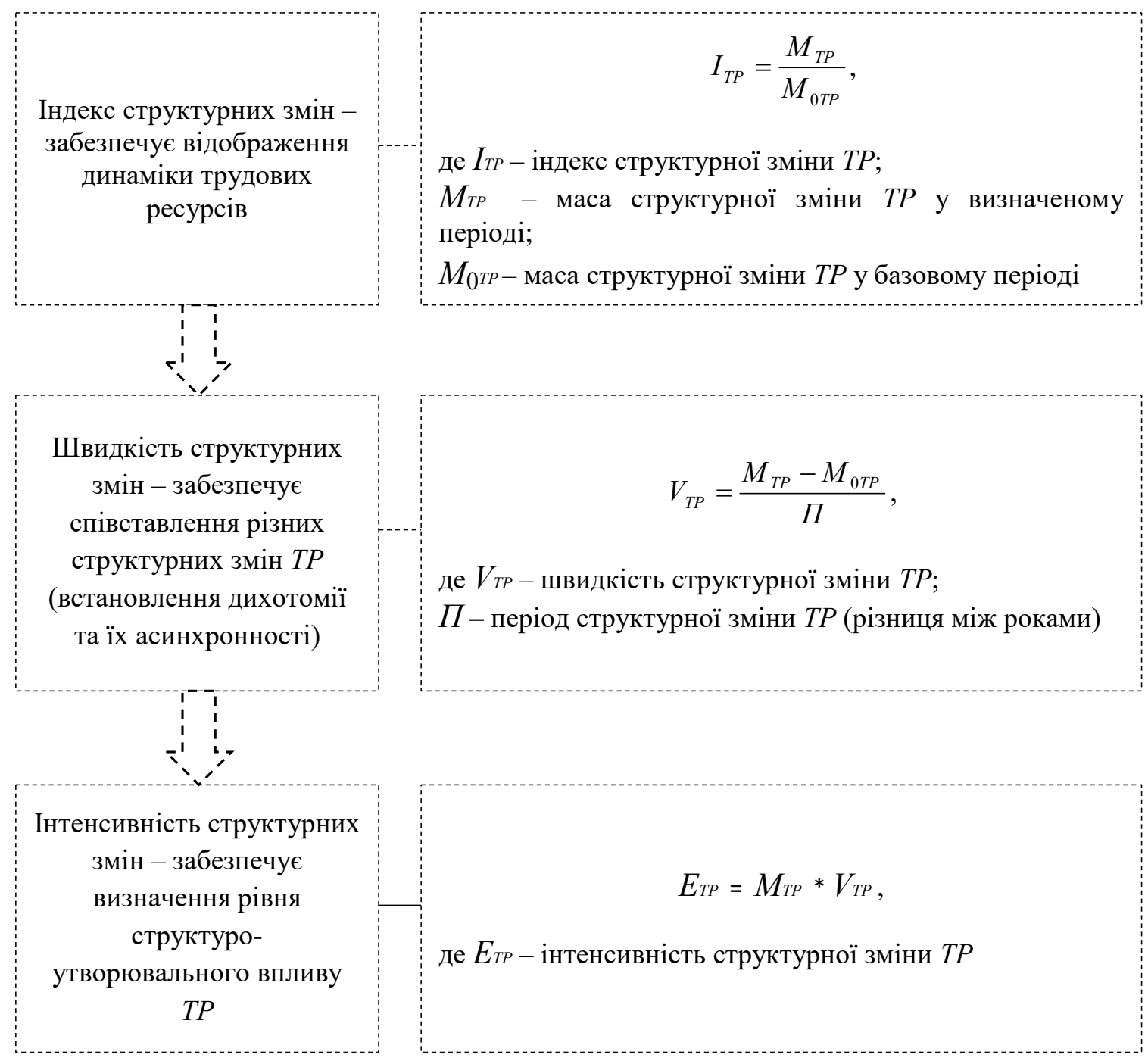

Рис. 1. Послідовність розрахунків структурних змін трудоресурсного забезпечення у процесі функціонування сільськогосподарських підприємств 
Таблиця 1

Результати розрахунків індексу, швидкості та інтенсивності структурних змін трудоресурсного забезпечення у процесі функціонування

сільськогосподарських підприємств протягом 2010-2019 рр.

\begin{tabular}{|c|c|c|c|c|c|c|c|c|c|c|}
\hline & 2010 & 2011 & 2012 & 2013 & 2014 & 2015 & 2016 & 2017 & 2018 & 2019 \\
\hline \multicolumn{11}{|c|}{ Сільське господарство } \\
\hline$M_{T P}$ & 6,58 & 6,39 & 6,54 & 6,47 & 7,27 & 6,77 & 7,01 & 6,73 & 6,34 & 5,87 \\
\hline$I_{T P}$ & & 0,972 & 0,994 & 0,985 & 1,105 & 1,029 & 1,066 & 1,023 & 0,964 & 0,893 \\
\hline$V_{T P}$ & & $-0,182$ & $-0,019$ & $-0,034$ & 0,173 & 0,038 & 0,072 & 0,022 & $-0,029$ & $-0,078$ \\
\hline$E_{T P}$ & & $-1,167$ & $-0,125$ & $-0,218$ & 1,257 & 0,259 & 0,506 & 0,147 & $-0,186$ & $-0,458$ \\
\hline \multicolumn{11}{|c|}{ Рослинництво } \\
\hline$M_{T P}$ & 4,79 & 4,69 & 4,97 & 4,95 & 5,73 & 5,34 & 5,62 & 5,51 & 5,18 & 4,76 \\
\hline$I_{T P}$ & & 0,980 & 1,038 & 1,034 & 1,196 & 1,115 & 1,172 & 1,149 & 1,081 & 0,994 \\
\hline$V_{T P}$ & & $-0,098$ & 0,090 & 0,054 & 0,235 & 0,110 & 0,138 & 0,102 & 0,048 & $-0,003$ \\
\hline$E_{T P}$ & & $-0,458$ & 0,448 & 0,269 & 1,344 & 0,587 & 0,773 & 0,562 & 0,250 & $-0,016$ \\
\hline \multicolumn{11}{|c|}{ Тваринництво } \\
\hline$M_{T P}$ & 1,48 & 1,44 & 1,25 & 1,20 & 1,19 & 1,12 & 1,04 & 0,87 & 0,84 & 0,80 \\
\hline$I_{T P}$ & & 0,968 & 0,844 & 0,805 & 0,799 & 0,751 & 0,700 & 0,585 & 0,566 & 0,541 \\
\hline$V_{T P}$ & & $-0,048$ & $-0,116$ & $-0,097$ & $-0,075$ & $-0,074$ & $-0,074$ & $-0,088$ & $-0,080$ & $-0,076$ \\
\hline$E_{T P}$ & & $-0,069$ & $-0,145$ & $-0,115$ & $-0,089$ & $-0,082$ & $-0,077$ & $-0,076$ & $-0,068$ & $-0,061$ \\
\hline
\end{tabular}

*де $M_{T P}-$ маса структурної зміни $T P ; I_{T P}$ - індекс структурної зміни $T P ; V_{T P}-$ швидкість структурної зміни $T P$; $E_{T P}-$ інтенсивність структурної зміни $T P$.

\section{Джерело: розраховано автором}

- позитивна динаміку виробництва продукції сільського господарства протягом 2013-2014 рр., на відміну від промисловості та будівництва (збільшення обсягів виробництва у 2014 р. простежувалося у 22 регіонах України);

- скасування мит та інших бар'єрів, які сильно обмежували поставки України на ринки ЄС;

- збільшення експорту сільськогосподарської продукції на 6,9 \% (796,3 млн дол.) (в основному за рахунок обсягів експорту зернових культур - $38 \%$, олії - 23,2 \% і насіння олійних культур - 7,8 \%) і зменшення імпорту на 19,6\% (на 1182,6 млн дол.).

Надзвичайно сильним негативним впливом на соціально-економічний розвиток України відзначився період поширення та загострення COVID-19 (рис. 3, 4). Попри значні зрушення, підприємства аграрного сектору за усіма видами діяльності продовжують фрункціонувати без особливих обмежень.

За деякими експертними оцінками, сільське господарство зазнає менш руйнівного негативного впливу пандемії у порівнянні 3 іншими секторами економіки. У тому зв'язку, вважається, що у перспективі аграрний сектор значно посилить свою "вагу" в економічній системі України.

Сьогоднішня соціально-економічна ситуація в українському селі далека від європей- ських стандартів життя, до яких вже багато років прагне наша держава. Нерозвинена інсрраструктура, недостатність фрінансування та, як наслідок, зниження рівня життя населення - проблеми, що хвилюють представників громад сіл і селищ. Поруч із сільським господарством повинні розвиватися і самі села, на території яких проводиться обробка землі. Проте, далеко не всі можуть відзначити результати соціально-економічного партнерства 3 аграріями, яким вдалося налагодили тісну співпрацю з бізнесом [6-10].

На нашу думку, взірцевим прикладом щодо підтримки сільського господарства у контексті сталого розвитку країни, зокрема сільських територій є Спільна аграрна політика (САП) Європейського Союзу. В цілях сприяння сільському господарству щодо задоволення вимог суспільства, САП наполягає на ефрективному виробництві продуктів харчування, що забезпечує максимальну віддачу для фрермерів і користь для споживачів та навколишнього середовища, шляхом [4]:

- трансформування методів виробництва та систем управління для зменшення використання пестицидів і добрив та найкращого використання природних, технологічних та цифррових рішень у процесі виробництва екологічно чистої якісної сільськогосподарської продукції; 

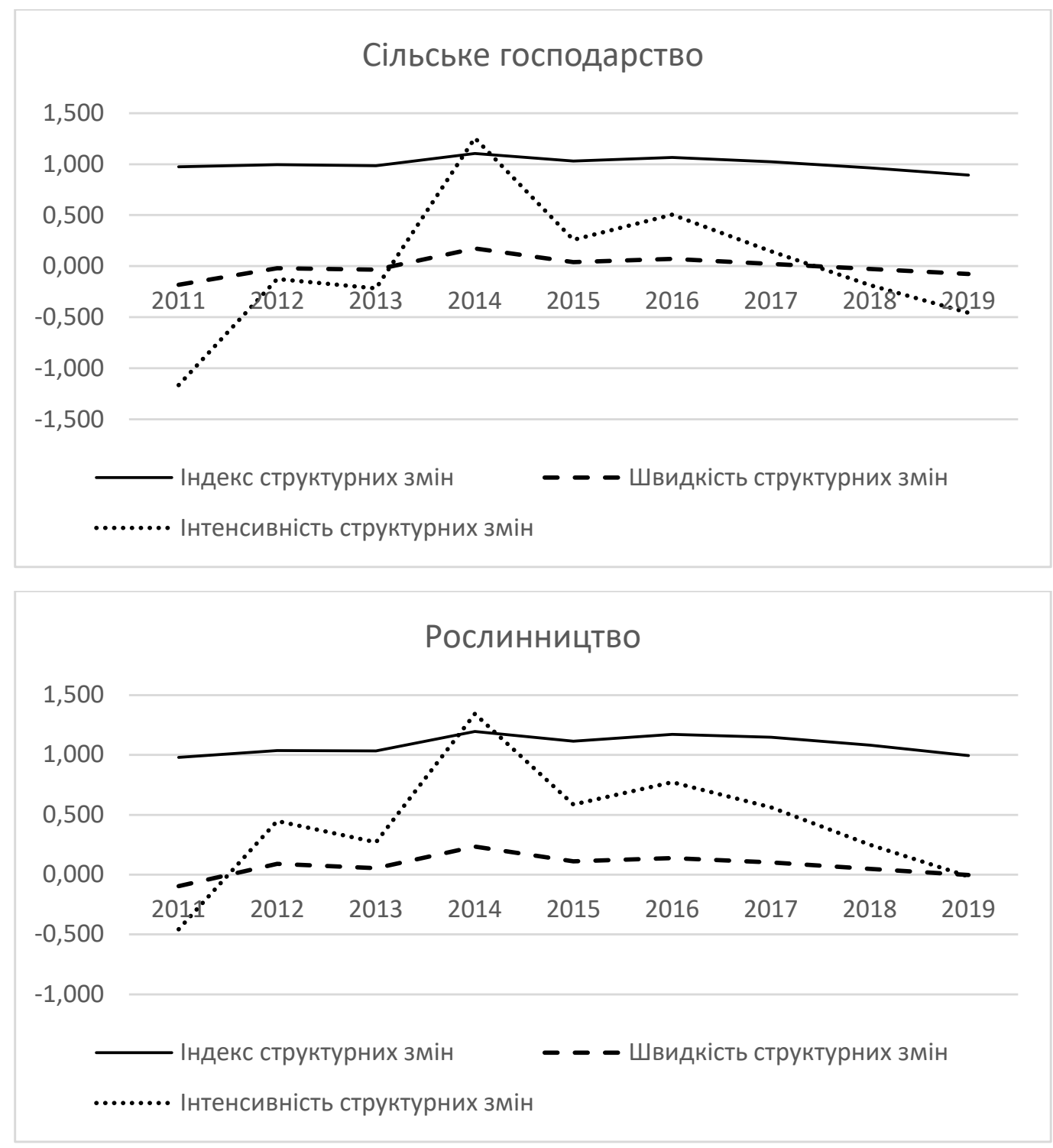

\section{Тваринництво}

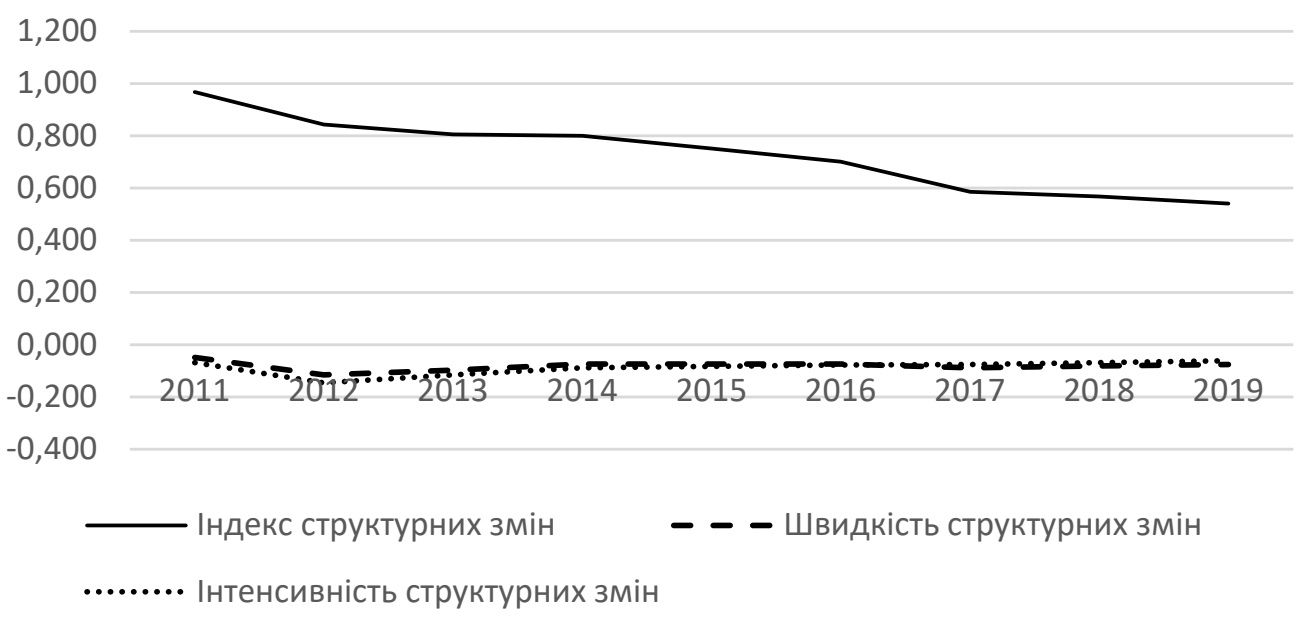

Рис. 2. Динаміка структурних змін у процесі трудоресурсного забезпечення сільського господарства 


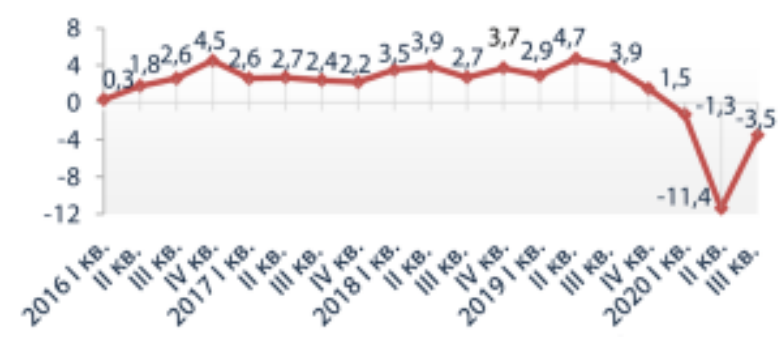

Зміна реального ВВП

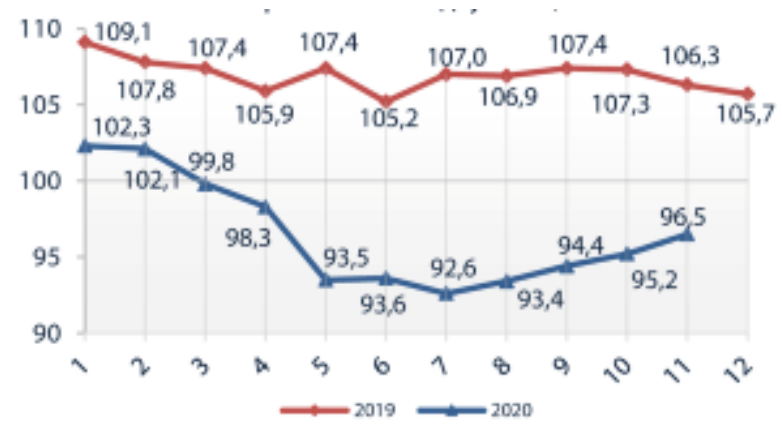

Темпи зростання експорту товарів

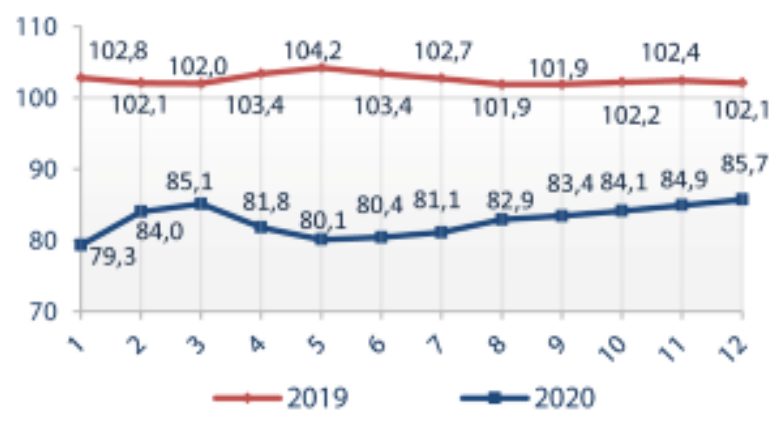

Індекс вантажообігу транспортних підприємств

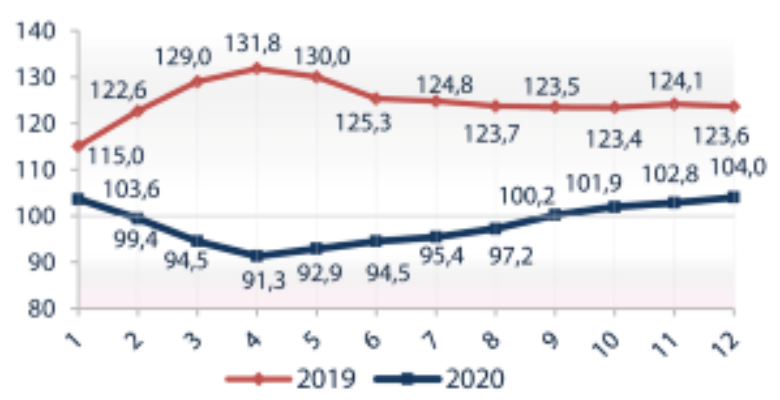

Індекси будівельної продукції

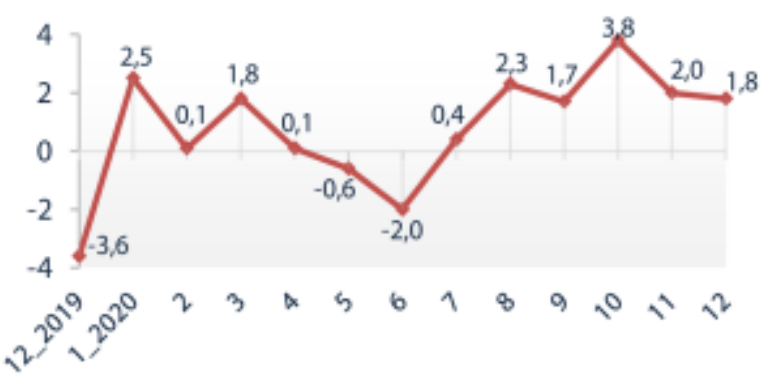

Зміна иін виробників

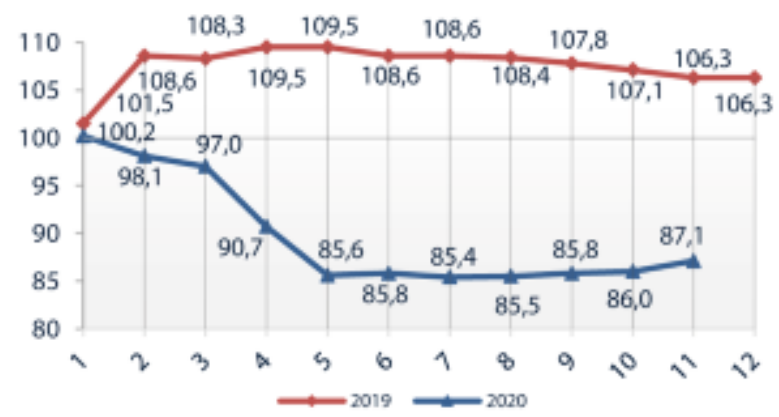

Темпи зростання імпорту товарів

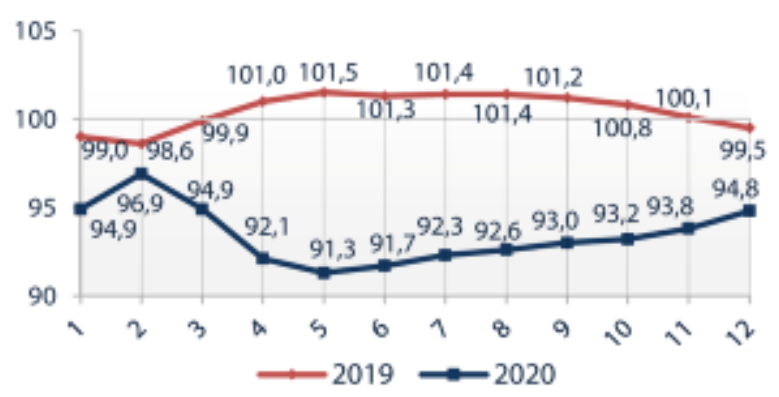

Індекси промислової продукиії

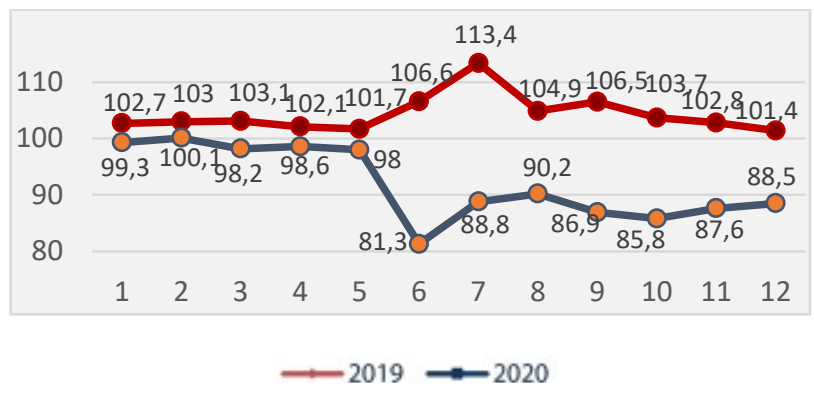

Індекси сільськогосподарської продукиії

Рис. 3. Динаміка скорочення основних економічних показників у період загострення COVID-19 в Україні

Джерело: сфрормовано за [2; 3]

- надання широкого спектру заходів підтримки, що зміцнюють прибуток сільськогосподарських підприємств та підвищують конкурентоспроможність їх продукції;
- фрінансування інформаційних та заохочувальних заходів для просвітництва споживачів про сільське господарство $€ \subset$ як безпечне та стійке джерело їх харчування. 
Сільське господарство виступає основою життєдіяльності сільських громад у цілому $€ С$. Ці громади стикаються з низкою проблем, таких як старіння демограсрічних показників, недостатньо розвиненою інфрраструктурою, а також відсутністю послуг та можливостей для працевлаштування.

Отже, САП сприяє стійкості сільських громад наступними шляхами:

- політика розвитку сільських територій націлена на соціальну інтеграцію, створення, диверсиорікацію робочих місць та розвиток сільської інфрраструктури;

- програми розвитку сільських територій також включають об'єднання сільських громад для підготовки та реалізації стратегій місцевого розвитку;

- додаткова підтримка фрермерів у районах, що стикаються 3 природними чи іншими специорічними обмеженнями, допомагає пом'якшити негативні соціально-економічні наслідки залишення земель, тоді як спеціальні виплати молодим фрермерам заохочують оновлення поколінь та довговічність сільського населення;

- завдяки спільній системі моніторингу та оцінки Комісія збирає вичерпні соціально-

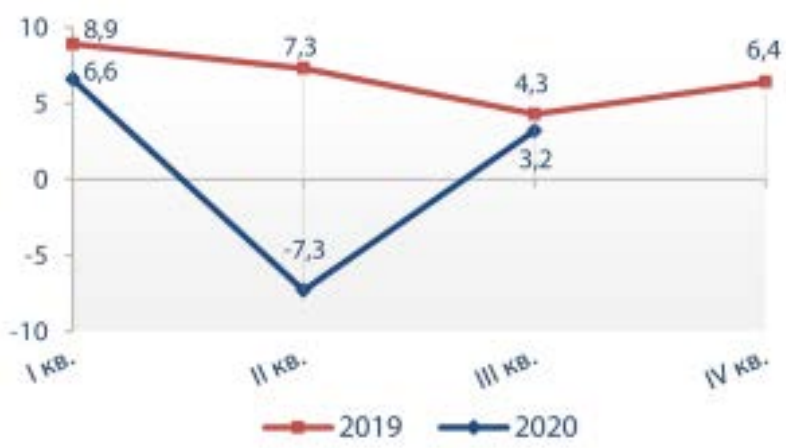

Зміна реального наявного доходу населення

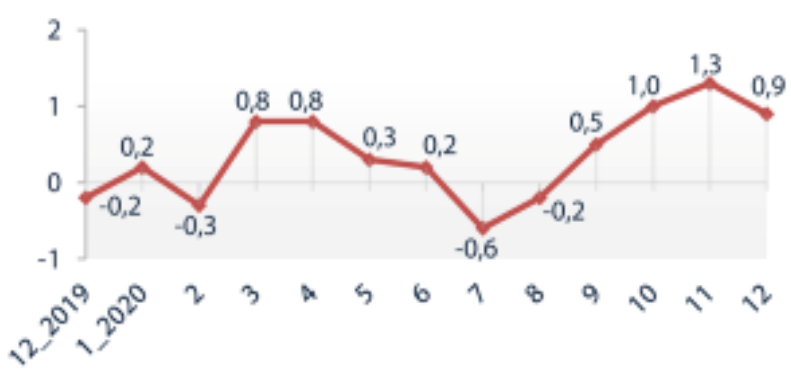

Зміна споживчих ијн економічні показники щодо сільських районів, приймаючи рішення на основі даних для таких основних соціальних питань, як депопуляція, бідність та безробіття.

САР також зміцнює відносини між сільськими громадами. Заходи, що забезпечують охорону ландшастів, дикої природи та природних ресурсів (чисте повітря та річки) корисні не тільки для сільського господарства та навколишнього середовища, але й також сприяють підвищенню якості життя в сільській місцевості та відкривають можливості для рекреаційної діяльності та туризму, надалі підтримуючи сільські громади.

Знання, дослідження та інновації покликані внести стратегічно важливі структурні зміни у соціально-економічному розвитку сільських територій, щоб забезпечити яскраве майбутнє сільських громад, зокрема:

Політика розвитку сільських територій підтримує інновації у сільській місцевості через сільськогосподарське європейське інноваційне партнерство, а також такі ініціативи, як "розумні села".

Дослідження та впровадження інновацій у політиці сільського господарства, а також під-

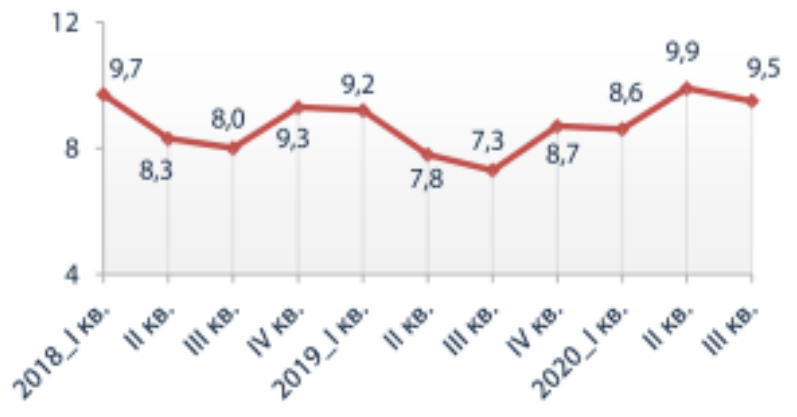

Зміна рівня безробіття населення

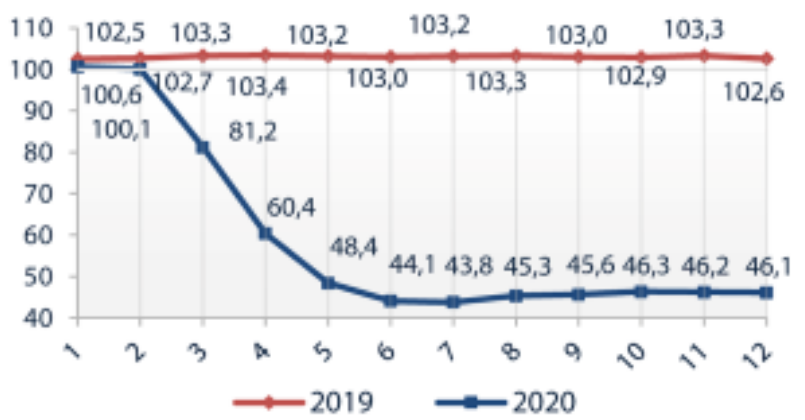

Індекс пасажирообігу транспортних підприємств

Рис. 4. Динаміка скорочення основних соціальних показників у період загострення COVID-19 в Україні

Джерело: сфрормовано за [2; 3] 
вищення ролі людського капіталу та стимулювання інноваційних систем сприяють підвищенню стійкості сільських громад та відіграють важливу роль у стимулюванні зеленого та соціально-інклюзивного економічного зростання.

Новітні технології також присвячені таким сорерам, як кругові харчові та непродовольчі ланцюжки вартості, екологічні підходи до фрермерського господарства та цифрове сільське господарство, що дозволяє досягти продовольчої безпеки без додаткового навантаження на навколишнє середовище.

Висновки. Сьогодні в Україні спостерігається ситуація, коли держава не в повній мірі може забезпечити населенню гарантії щодо усіх соціальних аспектів його якісної життєдіяльності. У тому зв'язку, найбільш активна частина суспільства - підприємці повинні приступити до пошуків власних методів вирішення соціально-економічних проблем. В наш час агробізнес інтегрує та поєднує в собі фрункціональну сукупність усіх сфер аграрного сектору, що, своєю чергою, забезпечує первинні потреби суспільства у продовольстві. Крім виробництва якісних продуктів і послуг, сільськогосподарські підприємства зобов'язані брати на себе додаткові зобов'язання перед суспільством за виконання різного роду соціально-важливих завдань у контексті сталого розвитку сільських територій.

\section{СПИСОК ВИКОРИСТАНИХ ДЖЕРЕЛ:}

1. Левківська Л.М., Швець Т.В. Соціальна відповідальність у контексті фрормування стратегічного розвитку сучасного агробізнесу. Економіка АПК, 2018. № 7. URL: http://eapk.org.ua/sites/default/files/eapk/2018/07/ eapk_2018_07_p_74_82.pdf (дата звернення: 04.12.2020).

2. Ооріційний сайт Державної служби статистики України. URL: http://www.ukrstat.gov.ua (дата звернення: 03.12.2020).

3. Офріційне Інтернет-представництво Міністерства розвитку економіки торгівлі та сільського господарства України. URL: https://www.me.gov.ua/?lang=uk-UA (дата звернення: 03.12.2020).

4. Поленкова М.В. Інституційні засади фрункціонування підприємств аграрного сектору ЄС в умовах сталого розвитку. Наукові записки Львівського університету бізнесу та права. Серія економічна. Серія юридична. 2020. Вип. 25. С. 87-92.

5. Поленкова М.В. Тенденції розвитку сільськогосподарських підприємств у період структурних змін в аграрному секторі України. Наукові записки Львівського університету бізнесу та права. Серія економічна. Серія юридична. 2020. Вип. 26. С. 42-47.

6. Степаненко Н.І., Скидан О.В., Швець Т.В. Стратегічні засади фрормування та розвитку обслуговуючих підприємств північно-західного регіону України. Агробізнес : проблеми, сучасний стан та перспективи розвитку : кол. моногр. / за ред. Я.В. Сухія, В.С. Ніценка. Одеса : СВД М.П. Черкасов, 2011. С. 263-300.

7. Стратегія сприяння розвитку соціальної відповідальності бізнесу в Україні на період до 2020 року. URL: http://svb.ua/sites/default/files/201309_strategiya_spriyannya_rozvitku_svb_v_ukrayini.pdf (дата звернення: 04.12.2020).

8. Boogaard, B. K., Boekhorst, L. J. S., Oosting, S. J., \& Sørensen, J. T. (2011). Socio-cultural sustainability of pig production: Citizen perceptions in the Netherlands and Denmark. Livestock Science, 140(1-3), 189-200.

9. Bos, J. F. F. P., Smit, A. L., \& Schröder, J. J. (2013). Is agricultural intensification in The Netherlands running up to its limits? NJAS-Wageningen Journal of Life Sciences, 66, 65-73.

10. Davis, K. F., Gephart, J. A., Emery, K. A., Leach, A. M., Galloway, J. N., \& D'Odorico, P. (2016). Meeting future food demand with current agricultural resources. Global Environmental Change, 39, 125-132.

\section{REFERENCES:}

1. Boogaard, B. K., Boekhorst, L. J. S., Oosting, S. J., \& Sørensen, J. T. (2011). Socio-cultural sustainability of pig production: Citizen perceptions in the Netherlands and Denmark. Livestock Science, 140(1-3), 189-200.

2. Bos, J. F. F. P., Smit, A. L., \& Schröder, J. J. (2013). Is agricultural intensification in The Netherlands running up to its limits? NJAS-Wageningen Journal of Life Sciences, 66, 65-73.

3. Davis, K. F., Gephart, J. A., Emery, K. A., Leach, A. M., Galloway, J. N., \& D'Odorico, P. (2016). Meeting future food demand with current agricultural resources. Global Environmental Change, 39, 125-132.

4. Levkivska, L.M., Shvets, T.V. (2018). Sotsialna vidpovidalnist u konteksti formuvannja stratehichnoho rozvytku suchasnoho ahrobiznesu. [Social responsibility in context formation of strategic development of modern agribusiness]. Ekonomika APK, no. 7. Retrieved from: http://eapk.org.ua/sites/default/files/eapk/2018/07/eapk_2018_07_p_74_82.pdf (accessed 04 December 2020). 
5. Ministry of Economic Development of Trade and Agriculture of Ukraine: Official Internet representation (2020). Retrieved from: http://minagro.gov.ua (accessed 03 December 2020).

6. Polenkova, M.V. (2020). Instytutsiyni zasady funktsionuvannya pidpryemstv ahrarnoho sektoru ES v umovakh staloho rozvytku [Institutional principles of functioning of EU agricultural sector enterprises in the conditions of sustainable development]. Naukovi zapysky Lvivskoho universytetu biznesu ta prava. Seriya ekonomichna. Seriya yurydychna, no. 25, pp. 87-92. (in Ukrainian)

7. Polenkova, M.V. (2020). Tendentsii rozvytku silskohospodarskykh pidpryemstv u period strukturnykh zrushen $\checkmark$ ahrarnomu sektori Ukrainy [Trends in the development of agricultural enterprises in the period of structural changes in the agricultural sector of Ukraine]. Naukovi zapysky Lvivskoho universytetu biznesu ta prava. Seriya ekonomichna. Seriya yurydychna, no. 26, pp. 42-47. (in Ukrainian)

8. State Statistics Service of Ukraine: Official site (2019). Retrieved from: http://www.ukrstat.gov.ua (accessed 03 December 2020).

9. Stepanenko, N.I., Skydan, O.V., \& Shvets, T.V. (2011). Stratehichni zasady formuvannia ta rozvytku obsluhovuiuchykh pidpryiemstv pivnichno-zakhidnoho rehionu Ukrainy [Strategic principles of formation and development of service enterprises of the north-western region of Ukraine]. Ahrobiznes: problemy, suchasnyi stan ta perspektyvy rozvytku: kol. monohr. - Agribusiness: problems, current status and development prospects: coll. monograph, pp. 263-300. Ya.V. Sukhii \& V.S. Nitsenko (Eds.). Odesa: SVD M.P. Cherkasov. (in Ukrainian)

10. Stratehiia spryiannia rozvytku sotsialnoi vidpovidalnosti biznesu v Ukraini na period do 2020 roku [Strategy for promoting the development of corporate social responsibility in Ukraine until 2020]. Retrieved from: http://svb.ua/ sites/default/files/201309_strategiya_spriyannya_rozvitku_svb_v_ukrayini.pdf (accessed 04 December 2020). 